\title{
MANAGING ENTREPRENEURSHIP EDUCATION IN HIGHER EDUCATION INSTITUTIONS - CASE ROMANIA
}

\author{
Daniel Badulescu
}

University of Oradea, Oradea, Romania

\author{
Alina Badulescu \\ University of Oradea, Oradea, Romania
}

(C) MESTE NGO

JEL category: A23, I23, L26

\begin{abstract}
Higher education institutions are facing growing challenges and therefore they must be pro-active in educating students and providing graduates able to develop and combine theoretical knowledge with skills and abilities required in the labor market. After analyzing students' motivations and expectations regarding the "added value" of the master studies in Business Administration, we found a solid confidence in the value and utility of master studies for their future careers. Moreover, entrepreneurship is a valuable alternative, even than lots of the expressed intentions are more declarative. The students' self-assessment regarding the knowledge and skills useful for a possible entrepreneurial career revealed some remarkable features. However, most of the students we had investigated are rather related to the traditional "by necessity" entrepreneurship. There is a relatively small share of traits able to stimulate innovative "by opportunity" entrepreneurship, as we could expect from young, well-educated and open-minded persons. Higher education institutions bear a large part of the responsibility of a correct orientation of students' potential towards an inspiring and prosperous entrepreneurship. Higher education institutions should constantly adapt the academic curricula to the requirements and challenges of the contemporary economy.
\end{abstract}

Keywords: entrepreneurial orientation, master students, entrepreneurial education, universities

\section{INTRODUCTION}

Besides the opportunities offered by the labor market (i.e. the employment per se), entrepreneurship enjoys an increasingly attention from young students. Therefore, understanding the entrepreneurial trends and attitudes among

Address of the corresponding author:

Daniel Badulescu

莑" dbadulescu@uoradea.ro undergraduate and master students (particularly in Business Administration) could provide deeper and clear insights on the relation between university education and the entrepreneurship requirements in the economic framework.

The subsequent implications are obvious: making adequate public policies to promote entrepreneurship among young people and adapting academic curricula, as to meet the students and employers' expectations, but also in response to the challenges of self-employment 
carrier. An adequate education may foster entrepreneurial intentions of an individual, as Turker \& Selcuk (2009, p. 144) have revealed: "Since the education offered by a university mostly influences the career selection of students, universities can be seen as potential sources of future entrepreneurs".

Our paper derives from a survey-based research conducted within master students in Business Administration from a Romanian public university. It aims at adding up to the already existing studies regarding the students' ability to capitalize master studies by entering into entrepreneurship. This paper attempts to clarify the following dilemma: to what extent the accumulation of knowledge and skills of high value leads young graduates to selfemployment?

Of course, a complete response could be given if we also know to what extent the university curricula are actually prepared for the "entrepreneurial option". In fact, the key question is whether young master students and graduates, and respectively, the "policy makers" are still excessively centered on obtaining / providing a Master's degree diploma, or the focus begins to move towards the intrinsic value of a well-trained graduate, holder of a single set of high-level knowledge, and able to use them in the entrepreneurial activity.

\section{BRIEF LITERATURE REVIEW}

Literature on entrepreneurship education is rich and diverse, addressing the nature, motivations and predictors, entrepreneurial traits, influence of the economic environment, policies to foster and enhance its effectiveness etc. Entrepreneurial behavior was attributed to the individual's personality traits (Baum, Frese, Baron, \& Katz, 2007) or to contextual factors, and it was recently integrated into models of entrepreneurial intentions.

Comparing entrepreneurial spirit of students in Hong Kong and Singapore universities, Ang and Hong (2000) have focused on the importance of personality characteristics. Henderson and Robertson (2000) explained entrepreneurial interest of students through their personal traits and background and the existence of external favorable factors.
Since intentions are the best predictor for actual behavior (Ajzen \& Fishbein, 1977), the research of Krueger et al. (2000) on the antecedents of entrepreneurial intentions among students has underlined the importance of disposition to selfemployment of young researchers. This willingness, properly guided, can help to a rapid and successful exploitation of the research results.

Lüthje \& Franke (2003) showed that all contextual factors perceived as barriers should be identified and diminished. Concurrently, higher education institutions should encourage the supporting elements by moving towards entrepreneurship. The symbiosis between the correct understanding of entrepreneurship and inspired educators will lead to higher levels of entrepreneurial intentions among students (Souitaris, Zerbinati, \& Al-Laham, 2007).

Veciana et al (2005), when analyzing the perception of students from Catalonia (Spain) and Puerto Rico (U.S.) on the entrepreneurs within society, found a positive perception on new venture desirability, but a significant circumspection on its feasibility. The authors have confirmed the presence of a strong correlation between the existence of an entrepreneur in the family and the intention to create a new venture.

Kuckertz \& Wagner (2010, p. 524), based on data collected from students and graduates in science, engineering and business programs from three European universities, found that students with a stronger orientation towards sustainable business are more likely to move towards entrepreneurship, but also business experience diminishes the positive relationship between orientation toward sustainable business and entrepreneurial intentions.

According to Mora \& Vila (2009), about $7-8 \%$ of the graduates from European universities choose to develop their own business immediately after graduation, and this percentage seems to be higher than the proportion of first degree graduates who work as self-employers. For Romania, the share of individuals having at least post graduate degree and involved in TEA (Total Early-Stage Entrepreneurial Activity) reported a strong growth, i.e. it increased from $11.25 \%$ (2007) to $22.75 \%$ (2011). At the same time, the share of the entrepreneurs considered as EB (Established 
Business Owners) having at least a post graduate degree increased from $6.64 \%$ (2007) to $13.22 \%$ (2011) (Petru, et al., 2011), testifying the fast growing entrepreneurial activity during last years (Badulescu \& Vancea, 2013).

\section{RESEARCH DESIGN}

Considering to investigate relevant issues on the subject of entrepreneurial attitudes, orientation and potential of graduate students, we have conducted an extended survey in February 2013 and developed a survey-based study. In the present paper we focus on students' opinion on the relevance of master studies in Business Administration regarding facilitating employability or future carrier expectations. Also, we have analyzed the entrepreneurial antecedents related to intentions and expectations, motivational factors for starting a business and, finally, the key skills and competencies to justify and substantiate (in students' opinion) the entrepreneurial option.

The questionnaire was administered to 123 master students in Business Administration (1st and 2 nd year) from the public university in Oradea, Romania, representing all the students enrolled in this program.

As descriptions of the respondents, $33 \%$ of them were full-time master students (without any job commitments), $3 \%$ work in the public sector, $54 \%$ work in the private sector and $10 \%$ were selfemployed. By gender, $71 \%$ of the respondents were female and $29 \%$ male; by residence, $66 \%$ of them live in cities, $10 \%$ in small towns and the $24 \%$ in rural areas.

\section{RESULTS AND DISCUSSION}

After graduation, half of the responding master students (i.e. $50 \%$ ) declare they intend to launch or to continue their entrepreneurial way, followed by those who wish/want/expect a job in the private sector as an employee (i.e. 28\%). A significant proportion (i.e. 13\%) wish to work in public sector and $7 \%$ consider other options (unspecified, but we assume certain indecision, lack of alternatives or less "standardized" options, such as temporary emigration etc.). The continuing education in the form of doctoral studies counts only few options (i.e. 2\%) (Badulescu \& Vancea, 2013).

What is the added value of the Master program in Business Administration they are enrolled in and how much they valorize such a program? Figure 1 (see below) reveals that the expectations of young people enrolled in these programs specifically refer to improving their employment opportunities and getting a better salary in the private sector (i.e. $83 \%$ of the respondents "partially agree" or "strongly agree" with this assessment) or in the public sector (i.e. $77 \%$ "partially agree" or "strongly agree" responses). The role of master programs in business to fostering a profitable entrepreneurial business is appreciated by $80 \%$ of the respondents.

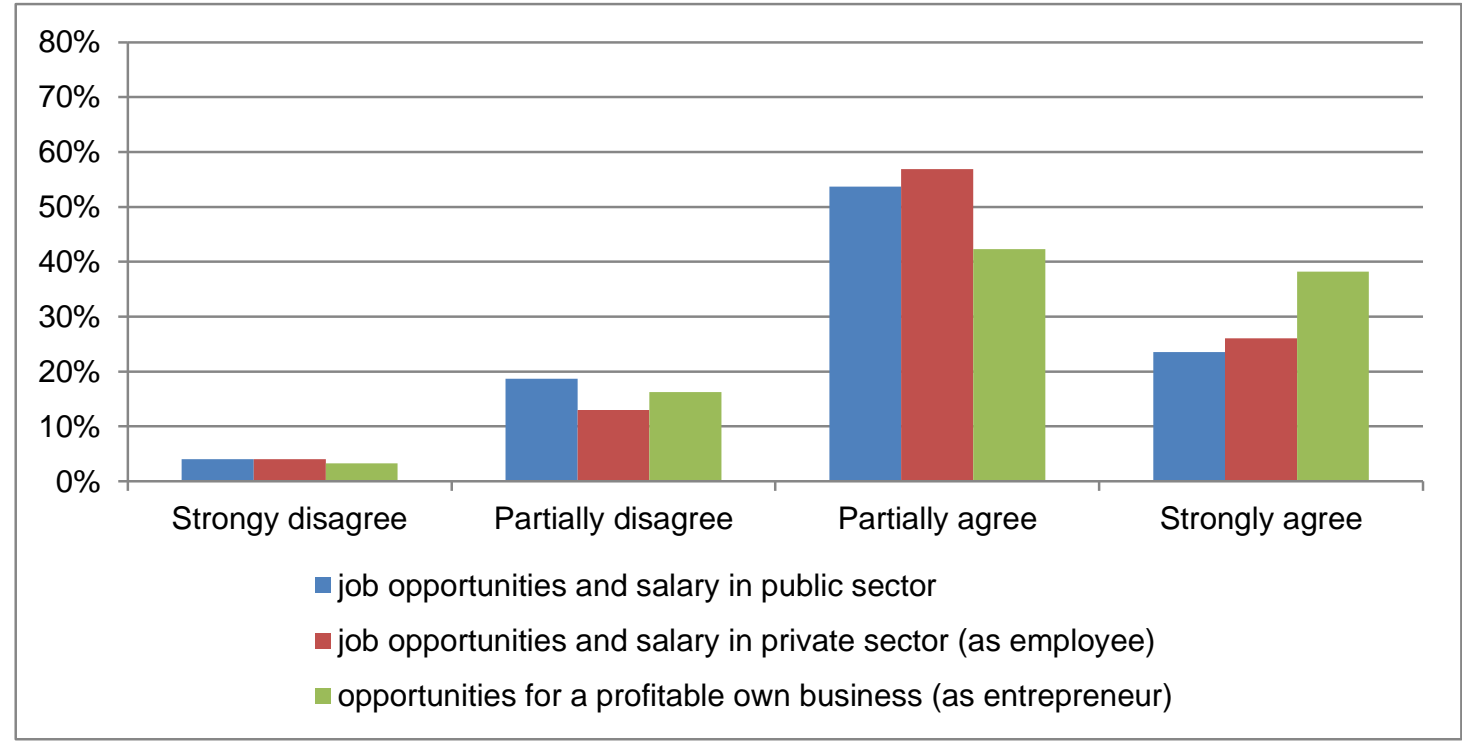

Figure 1. Responses to the question: "The master degree in Business Administration improves my ..."

(Source: authors' calculations based on dataset) 
Some negative assessments, such as: "Master in Business Administration does not improve my (job) opportunities (and salary) in ...." appear to be lower in the case of entrepreneurial option, but the figures and differences between public employee - private sector - self-employed people don't justify relevant interpretations in this matter.

As previously mentioned, a master program in business helps to exploiting opportunities in future career and gaining higher revenues. We will next investigate the areas where the master program and degree manifests its utility in students' opinion. The expectations for promoting career prospects count 93 options and the prospects for an independent and challenging career count 66 options out of the 123 respondents. Higher revenues expectations register 55 options, job security 44 options and the possibility to get an influence in society and politics gathers 13 favorable responses. However, 44 of the master students' options are prone to doubt of the benefit they will have from these courses. This relatively high number of skeptical options raises serious questions about the motivation in master courses attendance and, from the HEI part, the imperious need to improve the curricula for a higher satisfaction and more positive expectations. Moreover, we express some circumspection regarding the truthfulness and conformism of some respondents tempted by positive responses to this question. (Note: respondents could choose more than one response option).

The following issues refer to the transition from entrepreneurship as a possible option carrier, to entrepreneurship as an actual life alternative, and to give a measure how previous entrepreneurial experience shape the entrepreneurial intentions. In other words, it comes to reveal experiences versus entrepreneurial intentions among business master students. Thus, over $91 \%$ of the respondents (i.e. 112 students) said they would be interested to enter into entrepreneurship and launch their own business. The large number of entrepreneurial intentions seems to be a perfect start, but it should not be generalized. In this stage, there are only intentions expressed in a "friendly" framework, i.e. a survey conducted among students in "business", favorable to statements and "virtual raids" into entrepreneurship, but less of specific approaches.
This need to adjust the declarative options with the reality is underlined by the responses to the question regarding if people self-declared as interested in entrepreneurship have ever started a business, no matter this business is presently lasting or no. Thus, only 23 people (i.e. 19\%) declared they have ever started a business, but the large majority (100 persons, representing $81 \%$ of total respondents) admitted they have never started a business. The fact becomes even clearer when investigating how many of these businesses still work. The reason of this question is not just to identify a "critical mass" of businesses which really count, but also because entrepreneurship is a lifetime experience, an ability to survive and even prosper for the individuals and for the involved "stakeholders" (family, employees, customers, suppliers). Thus, more than half of those who mentioned the existence of a previous entrepreneurial business (i.e. 13 people out of 23) stated that this venture has stopped working.

As a brief summary, in quantitative terms, out of 123 master students, 112 are interested in entrepreneurship, 23 previously got entrepreneurial experience, but only 13 of them could be considered active entrepreneurs at the moment. In other words, 100 people (out of 123) studying business administration have never had to deal with an entrepreneurial experience / business, although most of them declared themselves as interested in entrepreneurship.

However, we should not be too disappointed or discouraged by the large gap between intentions and actual actions, as the large majority of respondents are young people under 25, belonging to the first age group entering the labor market. Moreover, as Shane (2009) revealed, a too early entry into entrepreneurship could prove to be an error, a major source of failures, discouragements and waste of human and financial capital for individual, family and society. Based only on naive enthusiasm, broad encouragement and simplified, idyllic visions on the entrepreneurial life, without a minimum experience and theoretical knowledge, the success will not occur soon.

The purpose of all these selected questions was to reveal not only the incidence of entrepreneurship among master students but also how they do understand the challenges of 
entrepreneurial careers and if and how they are actually prepared for this spectacular but risky world.

The next question refers to actual or potential motivations to entry into entrepreneurship. Table no. 1 (see below) captures these alternatives and their importance in shaping entrepreneurial intention. The highest scores (the most obvious adhesions) are related to the following motivations for entering into entrepreneurship: the expectation for higher earnings as motivator (i.e. 63 respondents, representing $51 \%$ ), the desire "to be your own boss" (i.e. 74 respondents, representing $60 \%$ ) and the desire "to do what I like" (i.e. 77 respondents, representing 63\%).

If we add up the scores assigned to the options "very important" and "important", the results are overwhelming, with $92 \%, 83 \%$ and $90 \%$ of the responses for each alternative mentioned before. By contrast, the strong disagreement (i.e. 93\%) for reasons such as "children are big enough" is explained by the very young age of the respondents. In the same reluctant register there are factors such as family entrepreneurial traditions (i.e. $63 \%$ ) or "the only way to exercise my profession" (i.e. 54\%).

Regarding the meaning of the distribution of responses on different alternatives and motivational assessments, some explanations are needed:

- On the one hand, it is expected that young students, at the beginning of their career, will choose entrepreneurship hoping it will bring consistent income, and it will quickly and directly (!) propel them in management position; they will do what they want (?) or they will be able to combine business demands with family duties. In realistic terms, beyond a disarming sincerity, choosing these options looks a lot of conformism, clichés and a large amount of future disappointments. In fact, consistent gains are not immediately achieved and the rate of business failures is devastating, especially among companies founded by inexperienced young people. The "boss" of small entrepreneurial firms is actually the "factotum" in the firm, from supply and distribution to labor relations and negotiations; and "doing what do you want" is far from the daily requirements of company's management. However, there are all powerful motivational drivers, throughout the world, even their emotional expression should be adjusted to the realities of the business world; - On the other hand, we deal with a second category of reasons, less visible, with no particular credit among master students, although we suppose their strong influence is manifested in more subtle ways. It is about the existence of business models and entrepreneurial tradition within the family, the willingness to implement their own idea for a product or service or to meet the challenges etc. Many of the reasons are completely depending on business experience, practical skills, success and even frustration.

- Finally, there are motivational and contextual factors about which young respondents have no experience or they were accidentally involved, through family, friends, school etc.: "to avoid unemployment", "the desire to live the current job", "children are big enough", or "the only way to exercise my profession". For these response options, rating them in a neutral position could be the best expression of cautious assessment on their impact on entrepreneurial option.

We could state that the distribution of responses and the group's specificities (i.e. young people with no significant job and life experience) makes difficult to find out the nature of the intended entrepreneurship, i.e. opportunity versus necessity entrepreneurship.

Even if young people are aware that they lack significant professional and life experience to objectively address the entrepreneurial challenges, this fact doesn't mean they are not aware of the importance of personal skills and competencies, inherited or acquired, in the managerial or entrepreneurial activity.

The following figure (Figure no. 2) lays-out a series of attributes and personal traits which are specific for entrepreneurial position, used to ask students' own assessment on them. As all these traits, in specific combinations, represent effective abilities and skills useful regardless the chosen career, we asked the respondents to choose only three of them, which they consider to be representative for their personal profile (thus, the total percentages exceed $100 \%$ ). 
Table 1. Factors which motivate starting a business

\begin{tabular}{|l|c|c|c|c|}
\hline & Unimportant & $\begin{array}{c}\text { Of little } \\
\text { importance }\end{array}$ & $\begin{array}{c}\text { Very } \\
\text { Important }\end{array}$ & important \\
\hline Prospects for higher earnings & 3 & 7 & 50 & 63 \\
\hline Willingness to meet the challenges & 6 & 33 & 57 & 27 \\
\hline Desire to be your own boss & 6 & 15 & 28 & 74 \\
\hline $\begin{array}{l}\text { Reconciling business demands with family } \\
\text { duties }\end{array}$ & 9 & 20 & 47 & 47 \\
\hline To avoid unemployment & 24 & 35 & 29 & 35 \\
\hline Desire to do what I like & 8 & 4 & 34 & 77 \\
\hline Desire to leave the current job & 49 & 42 & 21 & 11 \\
\hline Children are big enough & 93 & 19 & 9 & 2 \\
\hline It is the only way to exercise my profession & 54 & 45 & 18 & 6 \\
\hline Entrepreneurial tradition in my family & 63 & 36 & 13 & 11 \\
\hline $\begin{array}{l}\text { I want to implement my own ideas of product } \\
\text { or service }\end{array}$ & 17 & 29 & 46 & 31 \\
\hline
\end{tabular}

Source: authors' calculations based on dataset

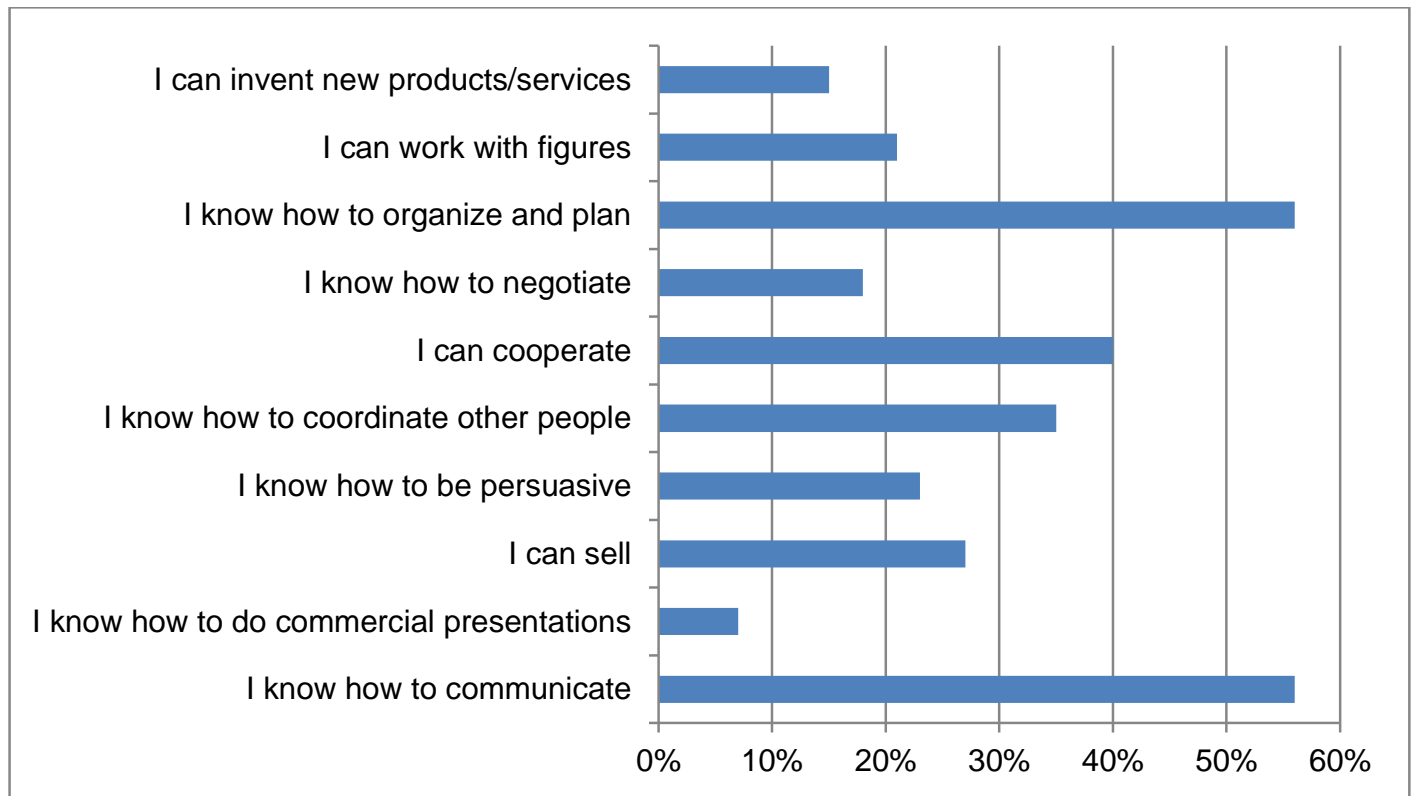

Figure 2 Which are, in your opinion, your three main skills/abilities?

(Source: authors' calculations based on dataset)

At first glance and as expected, students have a good opinion on their own abilities, and most of these meet the common requirements of entrepreneurship. Master students believe they know how to organize and plan (69 responses, i.e. $56 \%$ ), to communicate (69 responses, i.e. $56 \%$ ), to cooperate (49 responses, i.e. $40 \%$ ). By contrast, the ability to do commercial presentation ( $7 \%$ of responses) or to negotiate $(18 \%)$ are not as familiar for them.
We notice a solid optimism among master students on the skills they possess. A dose of enthusiasm and optimism above average is common and even desirable among entrepreneurs, as revealed by Cooper, Woo, \& Dunkelberg (1988) or Huang (2005). However, exaggeration, risks' assuming at any costs, building a false image of himself/herself could become serious threats in entrepreneurial decision. 
The sense of this question doesn't lies in the correlation between self-assessed traits and their actual existence in the personality of individuals, in other words if the person really knows how to organize, plan and communicate etc. It refers to and integrates the most important features of entrepreneurial personality, as it is seen by the students, based on presumption that many of these young people are, or will be, entrepreneurs.

It is worthy to find out the main features that they hope to use in the future profession, career and life. The "ideal entrepreneur" in the vision of interviewed master students seems to be a person with considerable planning and organizational skills, good communicator, team player (cooperative) and a good seller.

Even if the perspective is consonant to the reality, as the large majority of entrepreneurs with consolidated, profitable business have a combination of these traits, students projected a necessity and survival-driven entrepreneurship, focused on circumstantial results. Perhaps, this is due to difficult economic circumstances, market fragmentation and a lack of business models. For example, it is an unpleasant surprise for a highly educated person that some abilities registered modest scores, e.g. the "innovative capacity" with 18 responses (i.e. 15\%) and "the ability to promote ideas" or "negotiating" with $7 \%$ respectively $18 \%$. Opportunity-driven entrepreneurship is a far away eventuality in the students' plans. However, the overall picture is satisfactory, in line with the realities, and the main action recommended for all responsible and involve actors (i.e. $\mathrm{HEI}$ and students themselves) is to bring as much the selfassessed capabilities to current realities.

\section{CONCLUSIONS}

$\mathrm{HEI}$ and students are in the core of theoretical and practical debate on finding the optimal combination of high-value scientific knowledge teaching and the way to transform this knowledge into future viable and profitable ventures. Our research identified a significant interest of master students in Business Administration to acquire the necessary and relevant skills for their future career, whether this will be as employees in public or private sector or as entrepreneurs. However, our research also revealed the presence, for a significant part of the respondents, of a formal and declarative interest for entrepreneurship and a superficial knowledge of the realities and requirements of entrepreneurial careers.

Another concern arising from our research findings is related to the predominance of necessity-driven entrepreneurship, which is less connected to contemporary business dynamism and less able to capitalize the academic knowledge. If we add the over-evaluation of generic, difficult to assess skills, serious doubts occur on the effectiveness of master studies and the real motivations of participation in the programs of Business Administration.

The limited nature of our study did not allow us to capturing other determinants and features of the entrepreneurial approach, the extent to which HEI are actually prepared for labor market requirements, as to offer entrepreneurial education at high standards. However, an accurate and realistic attitude of master students towards entrepreneurship, nurtured by an adequate and up-to-date training and education could significantly enhance the role and impact of $\mathrm{HEI}$ on economic and social development.

\section{WORKS CITED}

Ajzen, I., \& Fishbein, M. (1977). Attitude-behavior relations: a theoretical analysis and review of empirical research. Psychological Bulletin, 84, 888-918.

Altbach, P. (2001). Academic freedom: International realities and challenges. Higher Education 41: , 205-219.

Ang, S., \& Hong, D. (2000). Entrepreneurial Spirit among East Asian Chinese. Thunderbird International Business Review, 42(3), 285-309.

Auriol, L. (2010). Careers of Doctorate Holders: Employment and Mobility Patterns. Paris: OECD. 
Badulescu, D., \& Vancea, M. (2013). Entrepreneurship as future career for post-graduate business students: a realistic option? 8th European Conference on Innovation and Entrepreneurship ECIE 2013, http://academic-conferences.org/ecie/ecie2013/ecie13-ab.

Baum, J., Frese, M., Baron, R., \& Katz, J. (2007). Entrepreneurship as an area of psychological study: an introduction. In J. F. Baum (Ed.), THe Psychology of Entrepreneurship. (pp. 1-18). Mahwah, NJ: Lawrence Earlbaum.

Boh, W. F., De-Haan, U., \& Strom, R. (2012). University Technology Transfer Through Entrepreneurship: Faculty and Students in Spinoffs. Ewing Marion Kauffman Foundation.

CEDEFOP (European Centre for the Development of Vocational Training). (2005). Improving lifelong guidance policies and systems. Using common European reference tools. Luxembourg: Office for Official Publications of the European Communities.

Cooper, A. C., Woo, C. Y., \& Dunkelberg, W. (1988). Entrepreneurs' perceived chances of success. Journal of Business Venturing, 3, 97-108.

Eurostat. (2010). Europe in figures. Eurostat yearbook 2010. Luxembourg: Publications Office of the European Union.

Fatoki, O. (2010). Graduate Entrepreneurial Intention in South Africa: Motivations and Obstacles. International Journal of Business and Management, Vol. 5(No. 9), 87-98.

Henderson, R., \& Robertson, M. (2000). Who Wants to Be an Entrepreneur? Young Adult Attitudes to Entrepreneurship as a Career. Career Development International, 5(6), 279-287.

Henkel, M. (2005). Academic identity and autonomy in a changing policy environment. Higher Education 49:, 155- 176.

Hooley, T., Bentley, K., \& Marriott, J. (2001, June). Entrepreneurship and UK doctoral graduates. Industry and Higher Education, pp. 181-191.

Huang, R. (2005). Industry Choices and Social Interactions of Entrepreneurs: Identification by Residential Addresses. Labor and Demography 0507010, EconWPA, (August).

Krueger, N., Reilly, M., \& Carsrud, A. (2000). Competing models of entrepreneurial intentions. Journal of Business Venturing, 15, 411-432.

Kuckertz, A., \& Wagner, M. (2010). The influence of sustainability orientation on entrepreneurial intentions - Investigating the role of business experience. Journal of Business Venturing, 25, 524-539.

Lee, S., Chang, D., \& Lim, S. (2005). Impact of Entrepreneurship Education: a Comparative Study of the US and Korea. The International Entrepreneurship and Management Journal, 1, 27-43.

Lüthje, C., \& Franke, N. (2003). The 'making' of an entrepreneur: testing a model of entrepreneurial intent among engineering students at MIT. R\&D Management, 33(2), 135-147.

Matis, D., Nagy, A., Petru, T.-P., \& Benyovszki, A. (2010). Entrepreneurship in Romania. Country report 2010. FSEGA - GEM - UBB Cluj-Napoca.

Mora, J., \& Vila, L. (2009). Some facts behind graduate's entrepreneurship in Europe. Revista de Economica, 35(3), 147-164.

Mora, J., \& Vila, L. (2009). Some facts behind graduate's entrepreneurship in Europe. Revista de Economica, Vol 35, 3, 147-164.

Petru, T.-P., Benyovszki, A., Gyorfi, L.-Z., Nagy, A., Matis, D., \& Pete, S. (2011). Entrepreneurship in Romania. 2011 Country Report. Global Entrepreneurship Monitor.

Shane, S. (2009). Why encouraging more people to become entrepreneurs is bad public policy. Small Business Economics, 33.

Slaughter, S., \& Leslie., L. (1997). Academic Capitalism: Politics, policies and the entrepreneurial university. Johns Hopkins University Press.

Smith, A., Bradshaw, T., Burnett, ,. K., Docherty, ,. D., Purcell, ,. W., \& Worthington, S. (2010). One Step Beyond: Making the most of postgraduate education. Department for Business Innovation and Skills, 43.

Souitaris, V., Zerbinati, S., \& Al-Laham, A. (2007). Do entrepreneurship programmes raise entrepreneurial intention of science and engineering students? The effect of learning, inspiration and resources. Journal of Business Venturing, 22, 566-591. 
The Ministry of Education, Research, Youth and Sports (Romania). (2011). Order no. 5272/2011 on admission to doctoral studies 2011-2012 academic year. Retrieved 07 26, 2012, from http://www.edu.ro/index.php/legaldocs/16074

Thrift, N. (2008). Research Careers in The UK: A Review. London: Department for Innovation, Universities and Skills.

Titgemeyer, M., \& Holtkamp, G. (2011). Entrepreneurial Attitude Among Doctoral Students: An Empirical Study. 6th European Conference on Innovation and Entrepreneurship.. Aberdeen, Scotland, UK: Dr Heather Fulford Centre for Entrepreneurship Aberdeen Business School Robert Gordon University.

Turker, D., \& Selcuk, S. (2009). Which Factors Affect Entrepreneurial Intention of University Students? Journal of European Industrial Training, 33(2), 142-159.

Veciana, J., Aponte, M., \& Urbano, D. (2005). University Students' Attitudes Towards Entrepreneurship: A Two Countries Comparison. International Entrepreneurship and Management Journal, 1, 165182.

Volkmann, C. K., \& Tokarski, K. O. (2009). Student Atitude to Entrepreneurship. Management \& Marketing, vol. 4, nr. 1, pp. 17-38.

Walsh, E., Hillemann-Delaney, U., Hargreaves, C., \& Li, J. (2010). Employability and Entrepreneurship - Perceptions of PhD students in China and the UK. Society for Research into Higher Education, Annual Research Conference 2010, (pp. 2-4). UK.

Received for publication:

Revision received:

Accepted for publication:
29.01.2014

10.05 .2014

23.06.2014

\section{How to cite this article?}

Style - APA Sixth Edition:

Badulescu, D., \& Badulescu, A. (2014, 07 15). Managing entrepreneurship education in higher education institutions - case Romania. (Z. Čekerevac, Ed.) MEST Journal, 2(2), 1-9. doi:10.12709/mest.02.02.02.01

Style - Chicago Fifteenth Edition:

Badulescu, Daniel, and Alina Badulescu. 2014. "Managing entrepreneurship education in higher education institutions - case Romania." Edited by Zoran Čekerevac. MEST Journal (MESTE) 2 (2): 1-9. doi:10.12709/mest.02.02.02.01.

Style - GOST Name Sort:

Badulescu Daniel and Badulescu Alina Managing entrepreneurship education in higher education institutions - case Romania [Journal] // MEST Journal / ed. Čekerevac Zoran. - Belgrade : MESTE, 07 15, 2014. - 2 : Vol. 2. - pp. 1-9.

Style - Harvard Anglia:

Badulescu, D. \& Badulescu, A., 2014. Managing entrepreneurship education in higher education institutions - case Romania. MEST Journal, 15 07, 2(2), pp. 1-90.

Style - ISO 690 Numerical Reference:

Managing entrepreneurship education in higher education institutions - case Romania. Badulescu, Daniel and Badulescu, Alina. [ed.] Zoran Čekerevac. 2, Belgrade : MESTE, 07 15, 2014, MEST Journal, Vol. 2, pp. 1-9. 